\title{
LIMITATIONS OF GEL FILTRATION FOR SERUM UNBOUND CALCILM AND MAGNESIUM
}

\author{
ELIZABETH L. PRUDEN AND PAUL L. CREASON
}

Caylon-Nickel Research Foundation, Bluffton, Ind.

AND WALTER D. BLOCK

Departments of Dermatology, School of Medicine and Health Development. School of Public Health. Universily of Michigan, Ann Arbor, Mich. (U.S.A.)

(Received April 12, 1969)

SUMMARY

Gel filtration techniques of determining serum unbound calcium and magnesium have been studied. Dry and pre-swelled Sephadex G-50 was used in procedures modelled on reported methods. Data are presented to support the conclusion that gel filtration, as a batch technique, remains unproved for the satisfactory quantitative estimation of unbound calcium and magnesium in serum.

Serum calcium exists in three forms: protein-bound, free ionic, and complexed in a small molecule ${ }^{1}$. Ionic and protein-bound forms interact to produce an equilibrium influenced by $\mathrm{pH}$, protein concentration, and to a lesser degree by temperature and other factors'. liree ions and complexes are identified as 'unbound, diffusible, ultrafilterable' species. Serum magnesium is believed to have similar forms and to exhibit similar behavior.

Because classic quantitative methods ${ }^{1-7}$ for serum unbound calcium and magnesium set high technical demands, gel filtration has been proposed $^{8-11}$ as a simple, rapid procedure. We have determined serum unbound calcium by both ultrafiltration and ultracentrifugation; each method has been found reproducible and values agreed well between methods. Using gel filtration methods, 10, however, we have found poor reproducibility and have obtained values which did not parallel those from other methods. We therefore undertook a study of factors involved in the gel filtration techniques of Schat $z^{8,9}$ and von Hattingberg and Klaus ${ }^{10}$.

\section{MATERIAL AND METHODS}

\section{Specimens}

A serum pool was used for replication experiments. Individual specimens were drawn from healthy, non-fasting staff members into Vacutainer* tubes, allowed to

* No. 3208, Becton-Dickinson, Rutherford, New Jersey. 
clot and centrifuged, still sealed, at room temperature. Serum was drawn off promptly for immediate $\mathrm{pH}$ measurement and addition to the respective prepared dextran samples. Portions were set aside for total calcium, total magnesium, and total protein determinations and for ultracentrifugation.

\section{Analytic methods}

Serum $\mathrm{pH}$ was measured at room temperature with an expanded-scale meter*. Calcium and magnesium were determined by atomic absorption spectrophotometry; protein was measured spectrophotometrically by difference in absorbance at 215 and $225 \mathrm{~m} \mu$.

\section{Reagents}

Sephadex**, G-5o, coarse. A single lot was used throughout the experiments.

Neutral saline, $0.9 \% \mathrm{w} / \mathrm{v}$ sodium chloride in deionized water, $\mathrm{pH}$ adjusted to 7.0 with $\mathrm{HCl}$ at $26^{\circ}$.

\section{Ultracentrifugation}

Up to 48 h elapsed between $\mathrm{pH}$ measurement and ultracentrifuge fractionation of the same specimen. Before centrifuging, each serum was carefully restored to its original $\mathrm{pH}$ by bubbling $5 \% \mathrm{CO}_{2}$. Specimens were fractionated by the method of Breen and Freeman ${ }^{7}$ at $30^{\circ}$. The protein-poor layer (Fraction I) of each was analyzed for calcium and magnesium concurrently with native serum.

\section{Gel filtration}

Dry dextran. Five ml of serum were added to $300.0 \mathrm{mg}$ dry dextran; the mixture was shaken mechanically for $75 \mathrm{~min}$ and then centrifuged. The procedure was that of Schatz ${ }^{8,9}$. The supernatant fluid was removed and labelled 'treated serum'. Calcium, magnesium, and protein concentrations, and in some instances $\mathrm{pH}$, were determined on it.

Pre-swelled dextran. The procedures were modelled after the unbound calcium method of von Hattingberg and Klaus ${ }^{10}$. They used Sephadex G-25 pre-swelled in

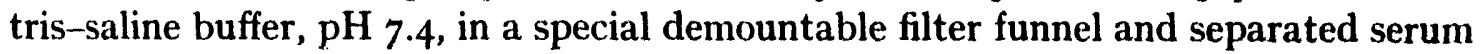
from gel by suction of standardized degree and duration. After experiments justifying the substitutions, we used G-50 swelled in saline ( $\mathrm{pH}$ 7.0). Separations were made in Sepra-Fuge*** tubes by standardized centrifugation in a floor model apparatus****.

\footnotetext{
* No. E 322, Metrohm Ltdl., Herisau, Switzerland.

* Pharmacia Fine Chemicals, Piscataway, New Jersey.

*** Occomy Associates, Chicago, Ill. Each Sepra-Fuge tube consists of two Lusteroid shells. The inner shell is supported on the lip of the longer (outer) one and has a number of pores irregularly distributed in and immediatcly above the bottom curvature. Passage of liquid through the pores may be effected by gravitational force, the outer shell serving as a collection receptacle. Gels or other residues remain in the inner shell. Least total capacity of tubes presently available is $30 \mathrm{ml}$. By selecting carefully only those inner shells with significant number of pores in the lowest point, we found the use of $30 \mathrm{ml}$ capacity tubes feasible in our procedures, even though a smaller inner shell with more pores in the bottom curvature would be more desirable for volumes under $10 \mathrm{ml}$. **** Model CS, International Equipment Company, Boston, Mass. Because prolonged centrifuging of swelled gel at high speeds risked compression and dehydration, we settled on conditions producing maximum separation of serum from the gel with minimum adverse effect on the gel itself. With the rheostat, the head of the centrifuge was brought smoothly and rapidly to proper tachometer reading, held $I^{1} / 2$ minutes at $3^{80} \mathrm{~g}$, then allowed to coast to a full stop. Each centrifugation was conducted in this manner.
}

Clin. Chim. Acta, 27 (1970) 19-28 
Two procedures were applied to each serum, always avoiding harsh mixing and inopportune dehydration of gels. Gel was fully swelled by allowing it to stand 16-18 hours at room temperature before use.

Procedure A. Two ml of well-mixed suspension of $1 \%$ dextran swelled in neutral saline (theoretically equivalent to $20 \mathrm{mg}$ dry dextran) were pipetted to the inner shell of a Sepra-Fuge tube.

Procedure $B$. Ten $\mathrm{ml}$ neutral saline were added to $300.0 \mathrm{mg}$ dry dextran in the inner shell of a Sepra-Fuge tube.

Immediately before analysis, gels $\mathrm{A}$ and $\mathrm{B}$ were centrifuged and separated. liquids discarded. Neutral saline was mixed with each gel residue $(A: 4.0 \mathrm{ml} ; \mathrm{B}$ : Io.0 $\mathrm{ml}$ ); the tubes were again centrifuged and separated liquids discarded.

Serum was next added to each gel (A: $1.0 \mathrm{ml} ; \mathrm{B}: 5.0 \mathrm{ml}$ ), mixed, allowed to stand $3 \mathrm{~min}$ and centrifuged. Collected liquids were saved, identified as 'treated sera', and analyzed for calcium, magnesium, and protein. The inner shells containing the gel residue were quickly weighed to the nearest $0.1 \mathrm{mg}$. Weight was identified as $W_{1}$.

Neutral saline was added to each gel (A: $4.0 \mathrm{ml} ; \mathrm{B}:$ 10.0 $\mathrm{ml}$ ), mixed, and immediately separated. The liquids were identified as 'wash solutions' and analyzed for protein content. The inner shells with their gel residue were dried overnight at $75^{\circ}$, and then reweighed to obtain $W_{2}$.

\section{RESULTS AND DISCUSSION}

Integrity of specimen and reliability of analytic methods are prerequisite to satisfactory evaluation of serum unbound calcium and magnesium. Prasad and Flink $^{3}$ found that reliable estimates of unbound calcium were obtained with anaerobic collection, careful handling, and prompt analysis of specimen. In order to reduce the number of experimental variables, we followed their example and eliminated saturation of specimen with $\mathrm{CO}_{2}$. Day-to-day coefficient of variation (C.V.) for the calcium method is $+1 \%$, for magnesium $+2 \%$, and range of recovery for both 97-101\%. At protein concentrations of $7.0 \mathrm{~g} / \mathrm{roo} \mathrm{ml}$, method C.V. is $+0.8 \%$, recovery $99-102 \%$. The $\mathrm{pH}$ of specimens when analyzed was 7.38 to 7.60 , reproducibility +0.05 unit.

\section{Ultracentrifuge analysis}

Measurement of calcium and magnesium in Fraction I provided directly

TABLE I

\begin{tabular}{|c|c|c|c|c|c|c|}
\hline SERUM UNBOUND & CALCIUM & AND MAGNESIUN & M CONCENTRATI & ONS: UL & ACENTRIFUGE & FRACTION 1 \\
\hline & $\begin{array}{l}\text { Calcium } \\
\text { mequiv/l }\end{array}$ & ll serum water & & $\begin{array}{l}\text { Magnes } \\
\text { mequiv }\end{array}$ & $m$ & \\
\hline & Total* & Unbound & $\%$ Unbound & $\bar{T}$ otal ${ }^{*}$ & Unbound & $\%$ Unbound \\
\hline 14 Subjects & & & & & & \\
\hline Mean & 5.01 & 2.98 & $5^{8.1}$ & I. 79 & 1.24 & 69.4 \\
\hline 土 I s.d. & 0.21 & 0.19 & 4.2 & 0.17 & 0.12 & 5.6 \\
\hline $\begin{array}{l}\text { Range } \\
\quad(95 \%)\end{array}$ & $\begin{array}{r}4 \cdot 59- \\
5 \cdot 43\end{array}$ & $\begin{array}{r}2.60- \\
3.26\end{array}$ & $\begin{array}{r}49.7^{-} \\
66.5\end{array}$ & $\begin{array}{r}1.45^{-} \\
2.13\end{array}$ & $\begin{array}{r}1.00- \\
1.4^{8}\end{array}$ & $\begin{array}{r}5^{8.2-} \\
80.6\end{array}$ \\
\hline
\end{tabular}

* Determined on native serum and corrected for protein to concentration per unit serum water. 
concentrations of unbound calcium and magnesium in serum water. Table I summarizes values obtained on 14 subjects. Replicability of a single value (in mequiv/l) was $\pm 2 \%$. Reproducibility of values found on a single subject at 5- to ro-day intervals was $4 \%$. Percentage unbound species relative to total concentration was calculated from total value corrected for protein to concentration per unit of serum water. In Table II, previously reported percentages found by appropriate methods have been compared to those we determined by ultracentrifugation.

TABLE II

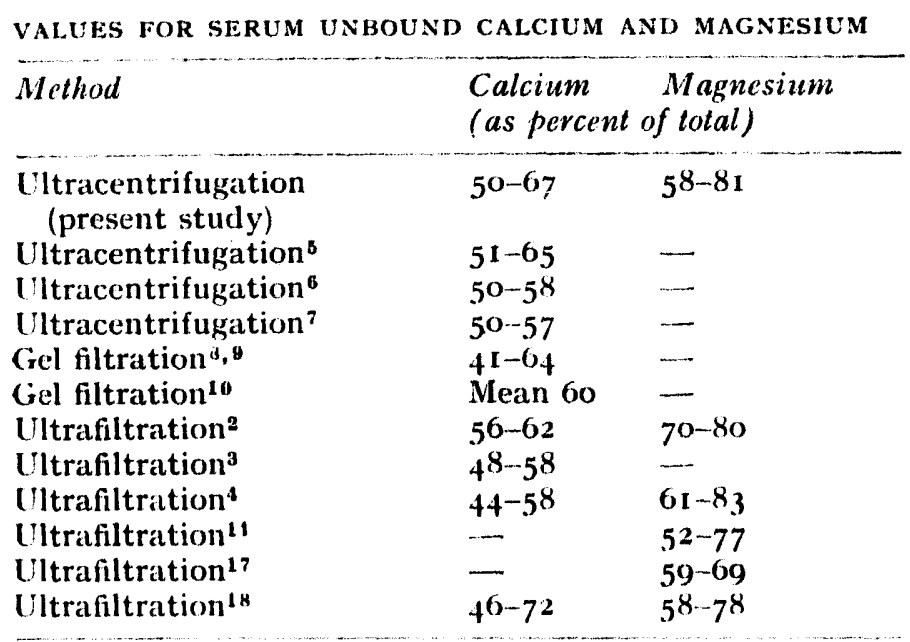

In this and an earlier series of analyses ${ }^{12}$, we detected an average amount of $3.5 \mathrm{mg}$ protein per milliliter of Fraction $\mathrm{I}$. When calculated from reported binding values $^{13-15}$, error in percent of total calcium existing unbound, due to presence of protein, was about $1 \%$; error in magnesium concentration was insignificant. For the purposes of this study, ultracentrifuge values for unbound species were defined as 'true' concentrations in sera examined by gel filtration.

\section{Gel filtration}

Originally proposed for qualitative protein separation ${ }^{16}$, gel filtration was applied by Schatz ${ }^{8,8}$, and later by von Hattingberg and Klaus ${ }^{10}$, to quantitative determination of serum unbound calcium. Rationale of these methods ${ }^{8-10}$ depended on the following premises:

(I) When serum is treated with dextran, the change that occurs in specimen calcium content represents a transfer of unbound calcium to a definable volume of water encompassed by the gel structure, from which the large moleculs s of proteins are excluded.

(2) Partition equilibria are established between intra- and extra-gel water and between concentrations of unbound calcium in intra- and extra-gel water.

(3) During the procedure, the ratio of protein-bound to unbound form persists undisturbed.

(4) At equilibrium, concentration of unbound calcium per unit of intra-gel water is a calculable function of the concentration of unbound calcium per unit of water of native serum. 
Because of these assumptions, the successful quantitation of unbound calcium and magnesium by these methods seems in great measure dependent on valid estimate of intra-gel volumes and on the effect of factors influencing partition and binding.

\section{Estimate of intra-gel volume}

For many purposes, intra-gel volume may be found from the aqueous regain value on the label of the particular kind and grade of dextran. Taking I $g$ water as $1 \mathrm{ml}$, regain represents intra-gel volume of $\mathrm{I} g$ of that dry dextran, when fullyswelled in aqueous media. We confirmed gravimetrically the stated aqueous regain of our Sephadex G-50 at $5.0 \pm 0.3 \mathrm{~g} / \mathrm{g}$ before use. Regain in saline was $5.40+0.12 \mathrm{~g}$ neutral saline solution/g Sephadex G-50.

When dry dextran was swelled in serum, serum protein concentration increased, thus defining a decrease in volume of serum water external to the swollen gel, and by inference, volume of serum water taken up by the dry dextran. We therefore calculated intra-gel volume $(R)$ from the increase in serum protein that occurred upon treatment of a specimen under study ( $R$ defines intra-gel volume for $300 \mathrm{mg}$ dry $\mathrm{G}-50$ in $75 \mathrm{~min})$.

$$
R=5.0 \mathrm{ml}-\frac{\text { Total protein, } \mathrm{g} / \mathrm{ml} \text { native serum } \times 5.0 \mathrm{ml}}{\text { Total protein, } \mathrm{g} / \mathrm{ml} \text { treated serum }}
$$

In procedures with pre-swelled dextran, as in the method of von Hattingberg ${ }^{10}$, the difference between wet and dried weight of gel exposed to a particular serum, $\boldsymbol{W}_{1}-\mathrm{H}_{2}$ in grams, was taken for volume of intra-gel water in milliliters. Reproducibility of intra-gel volume found in analyses of 16 sera by the three procedures is shown in Tabie III. Actual values are given for dextran exposed to 4 samples of pool.

Data for dry dextran swelled in serum (Table III) indicated wide variation in volumes regained from individual sera with somewhat less variation in replicates of pool. Even though the pool was a mixture, the volume it lost to dextran was as individualized as if it had been a separate, pure, single serum. From our observations, we concluded that the regain of water from a given serum by dry dextran was predictable neither from regain determined for aqueous solutions, nor from regain found for a serum pool, as Schatz's work would indicate ${ }^{8,9}$. Variation in intra-gel

TABLE III

\begin{tabular}{|c|c|c|c|}
\hline \multirow[t]{3}{*}{ Specimens } & \multicolumn{3}{|c|}{ Intra-gel volume in $\mathrm{ml}$} \\
\hline & \multirow[t]{2}{*}{ Dry dextran } & \multicolumn{2}{|c|}{ Pre-swelled dextran } \\
\hline & & Procedure A & Procedure $B$ \\
\hline \multicolumn{4}{|l|}{ Sera $(n=16)$} \\
\hline Mean & 1.34 & o. I 595 & 1.6197 \\
\hline \pm I s. d. & 0.14 & 0.0185 & 0.0362 \\
\hline$\pm \mathrm{IC.V.}(\%)$ & & $(11.6)$ & \\
\hline \multicolumn{4}{|l|}{ Pool aliquots } \\
\hline (I) & I. $3^{8}$ & $0.14^{68}$ & 1.644 I \\
\hline (2) & 1.49 & $0.23^{82}$ & 1.6542 \\
\hline (3) & I.43 & $0.145 \mathrm{I}$ & 1.6679 \\
\hline$(4)$ & I.5I & 0.1790 & 1.6490 \\
\hline
\end{tabular}


volume of dry dextran exposed to sera and pool appeared to indicate that water loss from a particular serum was an individual phenomenon, not consistently reproduced even in the same serum.

Pre-swelled dextran did not in procedure A provide a more reproducible estimate of intra-gel volume. Inhomogeneity of suspension or delivery of $2.0 \mathrm{ml}$ by pipette of somewhat viscid $\mathrm{r} \%$ susper.sion of gel, as recommended by von Hattingberg ${ }^{10}$, may have been the cause of the inconsistency. Actual dry weight of dextran present in procedure $A$ was usually less than the theoretical $20 \mathrm{mg}$ and frequently as little as $10 \mathrm{mg}$. Estimate of intra-gel volume was most reproducible in procedure $B$ where a weighed amount of dextran was swelled and exposed to serum without transfer.

\section{Fluid and unbound species partition}

Partition of fluid between intra- and extra-gel phases is reflected by change in protein concentration after treatment of serum by dextran. Osmotic effect, due to serum protein and electrolytes of the extra-gel fluid, undoubtedly governs the point of equilibrium for both fluid and unbound species. Schatz found neither fluid nor calcium exchange from 60 to 90 min after mixing $300 \mathrm{mg}$ Sephadex G-50 and $5.01 \mathrm{ml}$ serum pool $(7.3 \mathrm{~g} \text { protein per } 100 \mathrm{ml})^{8}$. From his data he determined a GibbsDonnan correction constant for use in calculating concentration of unbound calcium? Von Hattingberg found that serum applied to pre-swelled G-25 lost up to $2.5 \%$ of its volume to the gel in $3 \mathrm{~min}^{10}$.

Regain of water from individual sera by dry dextran, when calculated from change in protein concentration of 16 sera, was $4.48 \pm 0.46 \mathrm{~g}$ water/g G-50. The mean regain from 4 samples of pool was 4.84 with individual samples varying $+5 \%$ of the mean. Individual regains did not relate to protein content of the particular sera. Specimens of the same or nearly the same protein content provided regain values differing by as much as $0.7 \mathrm{~g} / \mathrm{g}$. In early experiments we noted that regain was roughly $10 \%$ greater from sera of less than $6.0 \mathrm{~g}$ protein per $100 \mathrm{ml}$ and 5 to I0 $\%$ greater from sera equilibrated with $5 \% \mathrm{CO}_{2}$ to $\mathrm{pH} 7.3$.

In procedures $A$ and $B$, fluid exchange between specimen and pre-swelled gel appeared probable whenever serum protein concentration changed upon treatment. Defining 'change' as before-after difference in excess of $\pm 2 \mathrm{C} . \mathrm{V}$. of the protein method error, we calculated percentage of volume gained or lost from the serum samples exposed to pre-swelled gel. Approximately half the sera in both procedures showed no volume change. In the remaining instances, increase of up to $6.5 \%$ and loss as great as $8.3 \%$ occurred; replicates of pool showed from $1.8 \%$ loss to 3.1 gain. There was no correlation between the two procedures in the occurrence, direction, or degree of volume change for a given specimen, nor did initial protein concentration relate consistently to character of observed change.

From the evidence of replicates of the pool, both unbound calcium and magnesium appeared to partition reproducibly in all three procedures. Differences between replicate concentration values of treated pool were no greater than differences between replicate values of native pool $(\mathbf{I}-\mathbf{2} \%)$.

Our findings seemed to indicate that fluid partition between serum and dry dextran, although perhaps responsive to protein content, $\mathrm{pH}$, and $\mathrm{CO}_{2}$ or bicarbonate content, is a phenomenon peculiar to a given serum specimen. Serum applied to 
pre-swelled dextran appeared to exchange fluid frequently and randomly with intragel phase during the period of contact.

Taken together, findings relative to estimate of intra-gel volume and fluid partition indicated that, in these simple indirect methods, partition mechanisms are not simple. Since the estimated intra-gel volume is a variable seemingly dependent on obscure characteristics of particular sera, and since an apparently reproducible means of volume estimate may often be marked by random fluid exchanges, none of the intra-gel volumes we found and tabulated can be certified as valid. When fluid partition cannot be precisely defined and is not reproducible, reproducible partition of unbound species becomes irrelevant.

\section{System $p H$}

Increasing alkalinity shifts binding equilibrium of calcium in favor of proteinbound species ${ }^{1}$. Von Hattingberg reported ${ }^{10}$ significantly lower values for unbound calcium in sera whose $\mathrm{pH}$ exceeded 7.60.

We determined $\mathrm{pH}$ on $\mathrm{Iu}$ specimens and on 4 samples of a single pool after treatment with dry dextran. Original $\mathrm{pH}$ of all samples was between 7.38 and 7.56 ; each showed $\mathrm{pH}$ increased after treatment by 0.15 to $0.4 \mathrm{I}$ units; a majority ended up with $\mathrm{pH}$ in excess of 7.60. We have found a similar degree of increase for sera adjusted with $5 \% \mathrm{CO}_{2}$ to $\mathrm{pH} 7.3$ prior to treatment.

Neutral saline and tris-saline (von Hattingberg's medium ${ }^{10}$ ), applied io dry dextran and recovered from the swelled gel, showed a rise in $\mathrm{pH}$-neutral saline from 7.0 to 8.6, tris-saline from 7.4 to 7.7. When fresh neutral saline and tris-saline were applied to wash fully swelled gel, both were recovered at their original $\mathrm{pH}$. We detected no change in $\mathrm{pH}$ in any serum sample recovered from pre-swelled gel after 3 min contact.

Such findings seemed to indicate that the swelling process of dry Sephadex G-50 alkalinizes ambient media to a degree governed by the buffering capacity of the medium. Once the gel is fully swelled, $\mathrm{pH}$ of wash solutions and sera briefly applied to it appears unaltered.

\section{Retention of applied protein}

Protein found in wash solution was considered by von Hattingberg ${ }^{10}$ to represent serum protein absorbed on and eluted from gel surfaces.

We calculated reproducibility of the absolute amount and of the percentage of applied serum protein which was recovered in the wash solutions of procedures $A$ and $B$ (Table IV).

Serum: gel ratio in procedure B offered three times more opportunity for retention than in procedure $A$, but the mean of absolute amounts recovered was almost the same for the two procedures and the percentage for procedure B was only one-sixth that of $\mathrm{A}$. We concluded that protein in the wash solution more nearly reflected amount of serum adhering to gel container surfaces than to gel surfaces themselves. The amount of serum retained is less significant relative to $5.0 \mathrm{ml}$ of applied serum than to $1.0 \mathrm{ml}$. The conclusion was supported by the respective reproducibilities for absolute amounts of protein in wash solutions of the two procedures.

Absolute amounts of protein were considered for a correction to be included in the calculating equation for quantitative estimates of serum unbound calcium and 
TABLE IV

REPRODUCIBILITY OF PROTEIN RECOVERED IY WASH SOLUTIONS

\begin{tabular}{|c|c|c|c|c|}
\hline \multirow{2}{*}{$\begin{array}{l}\text { Specimens } \\
\text { exposed }\end{array}$} & \multicolumn{2}{|l|}{ Procedure $A$} & \multicolumn{2}{|l|}{ Procedure $B$} \\
\hline & mg recovered & $\%$ recovered & mg recovered & $\%$ recovered \\
\hline \multicolumn{5}{|l|}{ Sera $(n=16)$} \\
\hline Mean & $\mathbf{1 . 8}$ & 2.84 & 1.7 & 0.44 \\
\hline $\begin{array}{l} \pm \mathrm{I} \text { s.d. } \\
\pm 1 \mathrm{C} . \mathrm{V} .(\%)\end{array}$ & $\begin{array}{l}\mathbf{I} \cdot 3 \\
\left(7^{2}\right)\end{array}$ & $\begin{array}{l}2.08 \\
(73)\end{array}$ & $\begin{array}{l}0.4 \\
(24)\end{array}$ & $\begin{array}{l}0.09 \\
(20)\end{array}$ \\
\hline \multicolumn{5}{|l|}{ Pool aliquots } \\
\hline (I) & 1.9 & 2.8 & 1.5 & 0.4 \\
\hline (2) & 1.2 & 1.9 & 1.2 & 0.4 \\
\hline (3) & I.8 & 2.7 & $1 \cdot 3$ & 0.4 \\
\hline$(4)$ & 0.5 & 0.8 & $1 \cdot 3$ & 0.4 \\
\hline
\end{tabular}

- Percent of total amount applied.

magnesium. In a majority of individual specimens a correction factor would have been considerably less than the inherent error of calcium- and magnesium-determinative methods.

\section{Calculation of concentration of serum unbound calcium and magnesium}

Schat $z^{8}$ found the range of concentration for 43 randomly pooled serum specimens to be 1.9 to 2.9 mequiv unbound calcium per liter serum; his individual values agreed well with unbound values derived by summation of average complex concentration with ionized concentrations taken from the McLean-Hastings chart ${ }^{1}$. His caiculating equation incorporated a fixed aqueous regain figure (label value) of his Sephadex, as well as a Gibbs-Donnan correction constant ${ }^{9}$. Although von Hattingberg and Klaus ${ }^{10}$ described only a mean percentage $(60 \%)$ of unbound calcium for I4 sera at physiologic $\mathrm{pH}$, range of values appears narrow. The method equation utilized wash solution protein content to correct for protein-bound calcium adhering to gel surface. We set up our calculating equations in keeping with our experimental findings. The only constants employed were those expressions representing sample volumes measured by pipette or unit conversion factors required for conventional description of concentration. Intra-gel volume $(R)$ for the dry dextran method was determined individually from change in protein concentration exhibitcd by each serum. In neither pre-swelled dextran procedure did we use a correction for retained protein; in both, $W_{1}-W_{2}$ in milliliters was taken as intra-gel volume. The equations were:

For dry dextran

mequiv unbound

calcium or

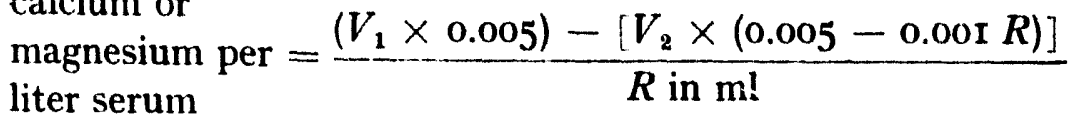

water

For pre-swelled dextran, procedure A

mequiv unbound

calcium or

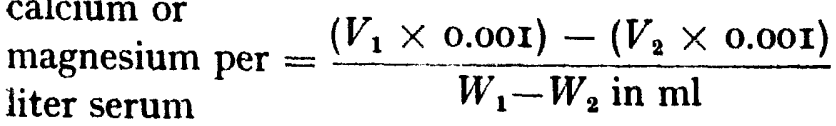

water

Clin. Chim. Acta, 27 (1970) 19-28 
For procedure B, which used $5.0 \mathrm{ml}$ sample, the factor $0.00 \mathrm{r}$ was replaced by 0.005 . $V_{1}$ and $V_{2}$ were calcium or magnesium concentrations (mequiv/l) as determined on native and treated serum respectively. $R$ and $W_{1}-W_{2}$ have been defined.

For each value determined by each dextran procedure, we calculated a coefficient of correlation with the corresponding concentration determined by ultracentrifuge. Table $\mathrm{V}$ summarizes means and variation of the coefficients of correlation for the methods; individual coefficients are given for samples of pool.

TABLE V

CORRELATION OF SERUM CONCENTRATIONS FOUND BY GEL FILTRATION AND ULTRACENTRIFUGATION

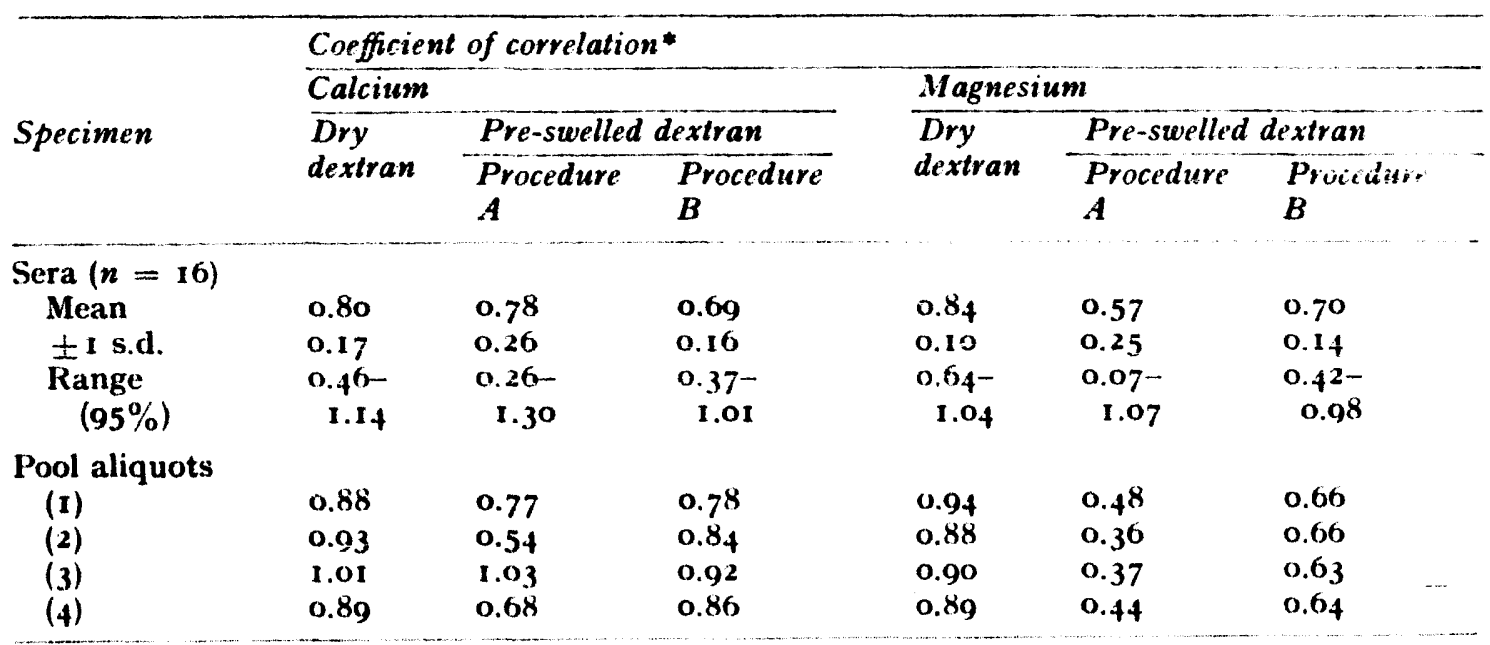

- Ultracentrifuge value $=1.00$.

Dextran method values tended generally to be lower than ultracentrifuge values. Correlation was so inconsistent as to defy interpretation. The pool replicates appeared to indicate some consistency of correlation within a particular dextran method for a single specimen's value.

We concluded that narrow ranges of unbound calcium concentration, previously reported for the dry dextran method ${ }^{8,9}$, were artifacts of calculation. When intra-gel volume and osmotic influence on it are translated into an equation as mathematical constants, the only variable remaining is the magnitude of calcium concentration change resulting from gel treatment. If intra-gel volume is used in the equation as the variable quantity we found it to be, calculated results for the dry dextran method diverge greatly and unsystematically, not only from corresponding values found by ultracentrifugation, but also from ranges generally accepted as physiologically probable.

With the pre-swelled dextran procedures we also found highly variable values. We had expected better of systems in which intra-gel volumes could be determined with rather fine precision, particularly in the instance of procedure $B$. That correlation was poor may relate to evidence of fluid exchange between serum and gel. Although we did not study modification of intra-gel volume by passage of wash solutions, the possibility of an effect remains and might partially account for the poor performance of the methods. 


\section{CONCLUSION}

We have investigated use of dry and pre-swelled Sephadex G-50 for quantitative estimation of serum unbound calcium and magnesium by gel filtration. Certain assumptions basic to the methods of Schat $z^{8,9}$ and von Hattingberg and Klaus ${ }^{10}$ appear open to doubt.

(I) Intra-gel vclume for dry dextran swelled in serum appears to be a variable phenomenon unique to the particular serum at hand. Definition of intra-gel volume from aqueous regain or pool regain is not certainly descriptive of actual regain from a particular serum. Serum specimens are sufficiently alkalinized by treatment with dry dextran to endanger the physiologic character of bound/unbound ratio of serum calcium.

(2) Fluid exchange of pre-swelled dextran during treatment with serum occurred frequently and at random. Such fluid exchange may be expected to alter estimates of intra-gel volume found from the protein concentration change occurring as a result of treatment.

(3) Concentration values for serum unbound calcium and magnesium, calculated usiag individually determined estimates of intra-gel volume, rather than empirically derived constants, correlated poorly with values for the same serum found by ultracentrifugation.

In view of such considerations, gel filtration methods for quantitative evaluation of serum unbound calcium and magnesium appear subject to serious limitations in general use.

\section{ACKNOWLEDGMENTS}

This work was supported in part by grant \#AM o2901, United States Public Health Service. The authors are indebted to Mr. K. John Jarrett, University of Michigan, and to Mrs. Roberta Lesh, Caylor-Nickel Research Foundation, for able technical assistance.

\section{REFERENCES}

I F. C. Mclean and A. B. Hastings, Am. J. Med. Sci., 189 (1935) 601.

2 W. G. Robertson and M. Peacock, Clin. Chim. Acta, 20 (1968) 315.

3 A. S. Prasad and E. B. Flink, J. Appl. Physiol., 10 (1957) 103.

4 J. R. Osmun, Amer. J. Med. Technol., 33 (1967) 448.

5 S. Ludewig, A. Chanutin and A. V. Masket, J. Biol. Chem., 143 (1942) 753.

6 H. F. Loken, R. J. Havel, G. S. Gordan and S. L. Whittington, J. Biol. Chem, 235 (1960) 3654 .

7 M. Breen and S. Freeman, Clin. Chim. Acta, 6 (1961) isi.

8 B. C. Schatz, Determination of protein-bound and unbound calcium in serum using dextran gel. M. S. Thesis, Univ. of Southern Calif., August, 1962. 47 p.

9 B. C. Schatz, cited in, R. J. Henry, Clinical Chemistry: Principles and Technics, Harper and Row, New York, 1964, p. 374-378.

io H. M. von HattingBerg and W. Klaus, Klin. Wochschr., 44 (1966) 499.

I I G. D. Lomax, J. Med. Lab. Technol., 24 (1967) 103.

12 E. L. Pruden, P. L. Creason, M. T. Creason and W. D. Block, Clin. Chim. Acta, 20 (1968) 173.

I F. C. Mclean and A. B. Hastings, J. Biol. Chem., 108 (1935) 285.

I4 B. E. Copeland and F. W. Sunderman, J. Biol. Chcm., I97 (1952) 331.

I5 A. S. Prasad, E. B. Flink and H. H. Zinneman, J. I.ab. Clin. Med., 54 (1959) 357.

I6 J. Porath, Biochim. Biophys. Acta, 39 (1960) 193.

17 A. S. Prasad, E. B. Flink and R. McCollister, J. Lab. Clin. Med., 58 (1961) 53 I.

8 M. Walser, J. Clin. Invest., 40 (1961) 723 . 